\title{
Equity and Excellence in Higher Education: A Case Study of Convergence in Kiss Odisha
}

\author{
Dr. Monalisa $\mathrm{Bal}^{1}$ \\ ${ }^{I}$ Chairperson, KIIT International School, Campu-9, KIIT University, Bhubaneswar-751024
}

\begin{abstract}
The Human Development Report (HDR) 2014 draws attention to India's poor performance in terms of Mean Years of Schooling and Gross Enrollment Ratio in Higher Education. This is despite introduction of Right to Primary Education and significant private sector initiatives in technical education. The paper tries to analyze the impact of Gross Enrolment Ratio (GER) on different sections of society: particularly the disadvantaged section and the quality of higher education and employability of students in terms of global opportunities. The various factors contributing to low quality particularly in public and private and state universities and major policy initiatives required to bolster quality and access have been highlighted. A unique experiment in KISS Odisha demonstrating coalescence between equity and excellence of tribal children has been cited.
\end{abstract}

Keywords: Human Development Report, Mean Years of Schooling, Grass Enrolment Ratio, KISS Odisha

\section{Introduction}

The Human Development Report (HDR) 2014 has brought out the persistent low score in terms of Human Development Index (HDI) (0.582) and low Mean Years of Schooling (MYS) (4.4) as against around 1112 years for most of the developed countries. Besides in case of higher education despite the substantial increase in Gross Enrolment Ratio (GER) from 10\% to around 17\% (2014) India position in GER is significantly lower than China (35\%), Russia $(75 \%)$ and USA $(95 \%)$. The $12^{\text {th }}$ plan aims at GER of $25 \%$ by 2017 while identifying Equity, Access and Excellence as the three thrust areas for achieving higher inclusive growth. The constitution explicitly provides for affirmative action in respect of disadvantaged section like SC/ST. As a follow up to the Sachhar Committee Report several initiatives have been taken in respect of Muslims. Despite such initiatives access to higher education remains asymmetrical amongst different sections of society. Further manifold reasons contribute to consistently mediocre quality in higher education barring a few elite institutions like IITs, IIMs, ISCs and National Law Schools.

\section{Objective Of Study}

1. Impact of various initiatives on ensuring equitable access to various sections of society and quality

2. Policy initiatives required for fostering quality particularly in public and private state universities

3. A case study showing convergence between equity and excellence in KISS Odisha

\section{Impact On Equity}

The constitution guarantees equality of opportunity to all section of society in terms of access to education and employment opportunities. Taking note of historical injustice to alienated communities like SC \& ST special provision were subsequently added in Article $15 \& 16$ to promote the goal of egalitarianism. The Supreme Court in M. Nagaraj case 2006 has endorsed such affirmative action by the state as not violative of right to equality. Income inequality is expressed in terms of GINI Coefficient and India shows a persistently high degree 0.334 despite the economic liberalization initiatives during the last two decades.

Since higher education provides an opportunity for high skilled employment. It would therefore be interesting to find how far GER of $16.7 \%$ has impacted different sections of the society \& promoted opportunities for higher employability in the global market.

Table-1 Impact of Access to Education on different Sections of Society

\begin{tabular}{|l|c|c|c|}
\hline \multicolumn{1}{|c|}{ Grouping } & $1999-2000$ & $2007-2008$ & Population Share \\
\hline SC & 5.1 & 11.6 & 16 \\
\hline ST & 6.4 & 7.7 & 7 \\
\hline MUSLIM & - & 9.6 & 13 \\
\hline OBC & 7.1 & 14.8 & 27 \\
\hline National Average & 10.1 & 17.2 & 100 \\
\hline
\end{tabular}

Source: National Sample Survey Organization Data 2006 
It would thus be seen from Table-1 that while there has been considerable improvement in access to education; the SC, ST \& Muslims do not have access to higher education commensurate with their population share. However, the Muslims, seem to be significantly lagging behind in terms of their representation in higher education despite implementation of Maulana Azad Fellowship Scheme and increase of the MAEF corpus to Rs.910 Crore during 13-14 as a follow-up to the Sachhar Committee Report (2006).

Interestingly different regions of India present a different picture in terms of access to higher education. Southern States lead the pack; while apathy rules the roost in Central and North-Central India as the Table-2 would reveal.

Table 2 Access to Higher Education: Inter Region

\begin{tabular}{|l|c|c|c|c|}
\hline \multicolumn{1}{|c|}{ Region } & SC/STs & Muslims & Hindus OBC & Hindus Upper Level \\
\hline South & 7 & 8 & 12 & 26 \\
\hline North & 7 & 7 & 11 & 26 \\
\hline North-Central & 4 & 3 & 6 & 20 \\
\hline Central & 3 & 5 & 6 & 25 \\
\hline Western & 5 & 7 & 9 & 25 \\
\hline North-Eastern & 3 & 3 & 6 & 13 \\
\hline
\end{tabular}

Source: National Sample Survey Organization Data 2006

\section{Impact On Quality}

Knowledge is the driving force in the rapidly changing globalized economy and society. The emergence of India as a knowledge-based service driven economy has made its human capital its major strength and opportunity for growth. According to a report by ICRIER, New Delhi, India is home to the world's largest pool of scientific and knowledge workers and produces 400,000 engineers per year while the US produces 60,000. According to the same report, in August 2006 India filed 1312 patent applications second only to the United States. This indicates that on the science and technology side, India has built up the largest stock of scientists, engineers and technician. In order to sustain these positive trends and an economic growth rate of $7 \%$, a venture Intelligence calculates that India's higher education gross enrollment ratio (GER) would need to increase from 12 to 20 percent by 2014 .

According to a recent government report $2 / 3^{\text {rd }}$ of India's college and universities are below standards. Further the previous HRD Minister had assessed that we will need 800 new universities and 40000 new colleges to meet the aim of $30 \%$ GER by 2030 . Such a massive expansion would need to have significant private sector initiatives. Besides to ensure quality foreign universities of repute would need to be invited to either set independent operations or collaborate with existing Indian universities. The initiative taken by the present government to set up 5 more IITs and IIMs is therefore eminently welcome.

The best of global practices reveals that research teaching and industry needs have to be sync. Unfortunately in India this troika has rarely synergized reflective the lamentable trends in industry university interaction and publication in reputed journals as the following Table-3 will reveal.

Table 3 Education Sector: Publication Trends

\begin{tabular}{|c|c|c|c|c|c|c|}
\hline \multirow{2}{*}{ Year } & \multicolumn{2}{|c|}{ India } & \multicolumn{2}{c|}{ China } & \multicolumn{2}{c|}{ USA } \\
\cline { 2 - 7 } & Public & Highly Cited Art & Public & Highly Cited Art & Public & Highly Cited Art \\
\hline 2001 & 15522 & 103 & 25730 & 174 & 150817 & 2894 \\
\hline 2011 & 36456 & 191 & 122672 & 980 & 184253 & 3137 \\
\hline
\end{tabular}

Source: YuXie Chunni Zhang et al at National Academy of Sciences, 2014

One related issue is the policy approach of the government; whether to foster only the elite academic institutions like IITs, IIMs and IISC or to broad base allocation to state universities in a massive way. China and Russia have adopted the elitist route, i.e. to promote a few select universities to improve their position in the Global Pecking Order.

It would be in the fitness of things to bring out that Total Factor Productivity (TFP) as brought out by Robert Solow is the key factor for the phenomenon growth of countries like USA after the Second World War. TFP can be defined as $\mathrm{Y}=\mathrm{A}^{*}\left(\mathrm{~K}^{\beta *} \mathrm{~L}^{\alpha}\right)$ where a $\mathrm{Y}$ refers to National Income, $\mathrm{A}$ to the level of technology and Scale, $\mathrm{K} \& \mathrm{~L}$ as Capital and Labour and $\beta \& \alpha$ as respective factor intensity. For India to be a major global manufacturing hub and contributor to the services sector globally the quality of labour in terms of skill dissemination, quality of education becomes critical.

\section{Major Areas For Policy Re-Orientation}

(a) FDI in Higher Education

Suhag and Rani (2013) have brought out that FDI in higher education will bring in quality programmes from foreign universities of repute and will improve market orientation. Given the fact that only around Rs.2051 
crores came of India since 2001 as FDI with $75 \%$ from Mauritius to Manipal University, there is a need to encourage inflow of FDI and setting up viable Joint Venture enterprises \& MoU with these companies. The position of FDI inflow over the years is shown as Figure-1.

Figure 1FDI Inflow \& Higher Education Sector

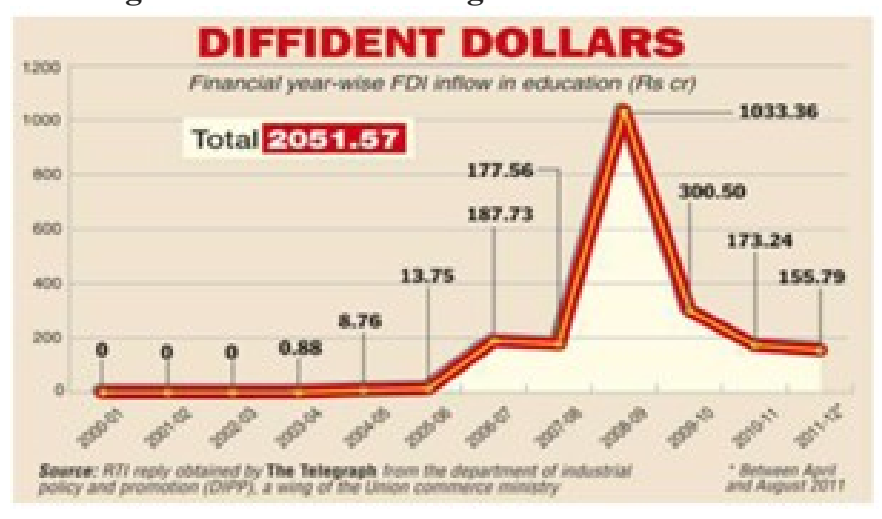

Source: RTI reply obtained by The Telegraph from the department of industrial policy and promotion (DIPP), a wing of the Union Commerce Ministey-April-Aug-11

\section{(b) Public Private Partnership (PPP)}

Sectors like telecom, airports, national highways and power have witnessed significant progress through Public Private Partnership models and have brought in significant FDI inflow into the country. During the $12^{\text {th }}$ plan an investment of one trillion dollar is proposed through a PPP route within the ratio of 50:50. While economic infrastructure is very high on government agenda the social infrastructure like education which is a vital complement to overall economic growth has been given a short shrift.

It would be worthwhile to draw experience of other countries like Sweden, Germany, Singapore \& China where the PPP model has worked wonders. The key success factors have been agreement on shared objectives from the beginning of the partnership and political will for participation of the private sector, transparency and accountability within the PPP. Sweden has regarded higher education as a 'merit good' and has a long tradition of substantial public spending. It has substantive relationship with the private sector which includes sharing of roles, responsibility, risks and rewards. In Germany, public commitment to take most risks has encouraged many small private enterprises to participate in the PPP model. Such models have important lessons for India.

\section{(c) Regulatory Mechanism}

The Yashpal Committee and Knowledge Commission have strongly recommended for establishment of an autonomous overarching National Commission for Higher Education and Research for prescribing standards of academic quality and defining policies for advancement of knowledge in higher educational institutions. Besides accreditation in higher education should be done through an Independent regulatory authority.

There is a near unanimity in view that existing regulatory control by UGC, created under Act of 1956 is not lending itself to quality improvement flexibility in charging fees, offering reasonable remuneration to teachers \& finalization of curriculum of either public or private universities. UGC's primordial concern is with central and elite universities like DU, JNU etc. This has to be abdicated in favour of a regulatory mechanism which is academically less asphyxiating. Arvind Panagariya (2012) makes a powerful plea against such frustrating control mechanism of UGC and recommends privatization to bring quality improvement.

In this context is must be mentioned that there is a dissonance in the approach of the UGC and Knowledge Commission under Mr. Pitroda. While the UGC is pitching for greater inclusivity and improving GER in small places which name less than the national average, the Knowledge Commission is aiming at exclusivity, augmenting framework for encouraging private players and foreign collaboration and maximal cost recovery through tuition fees. An independent regulatory body with the thrust to improve research and collaboration should be seriously looked at.

\section{(d) Allocation}

It may be recalled that Dr. Kothari (1964) had recommended that the government should spend atleast $6 \%$ of its Gross Domestic Product on education. However in over 45 years we have been able to achieve around half its target. The Knowledge Commission under Sam Pitroda (2009) additionally recommended an increase of atleast $1.5 \%$ of GDP for higher education. It would, therefore, useful to look at the comparative position shown 
in Table- 5 in respect of allocation by developed countries and BRIC countries and the success they have achieved in terms of HDI, GER \& MSY.

Colclough and Lewin (1993) in a seminal study have worked out a methodology for calculating investment requirement to finance universal primary education in India. Their study shows that around $3.1 \%$ of GDP needs to be allocated to universalize primary education as against around $1.5 \%$ earmarked by government.

Table 4 GER, HDI \& Education Expenditure as \% of GDP

\begin{tabular}{|c|c|c|c|c|c|}
\hline Country & GNI & HDI & GER & Mean Year of Schooling & Education Expenditure as \% of GDP \\
\hline USA & 52308 & 0.914 & $95 \%$ & 12.6 & 5.6 \\
\hline UK & 35002 & 0.892 & $61 \%$ & 12.3 & 5.6 \\
\hline Germany & 43409 & 0.91 & $57 \%$ & 12.9 & 5.1 \\
\hline Japan & 36747 & 0.89 & $60 \%$ & 11.3 & 5.6 \\
\hline France & 36629 & 0.88 & $51 \%$ & 11.1 & 3.8 \\
\hline Russia & 22617 & 0.778 & $75 \%$ & 11.8 & 5.9 \\
\hline Korea & 30345 & 0.89 & $100 \%$ & 7.5 & 4.1 \\
\hline China & 4477 & 0.79 & $35 \%$ & 4.4 & 3.7 \\
\hline India & 5150 & 0.586 & $23 \%$ & 3.3 & \\
\hline
\end{tabular}

Source: Human Development Report 2014

\section{(e) Research and Development}

Research and higher education are complementary to each other. According to HDR 2014 the expenditure on R\&D in the field of Science \& Technology as a percentage of gross domestic product (GDP) was $0.8 \%$ in the year 2012-2013 in India. However developed countries like Korea (3.7\%), Japan (3.4\%), USA $(2.9 \%)$ and Germany $(2.8 \%)$ spend substantially higher amount compared to India. India's higher education institutions are poorly connected to research centres and there is no synergy between research initiatives and industry requirement.

\section{Unique Experiment In Kiss Odisha Towards Convergences Between Equity and Excellence}

It would be interesting to study how a unique experiment in social inclusion through education of tribals in Kalinga Institute of Social Sciences (KISS) has fostered not only educational excellence but also extracurricular activities of the tribal students. Odisha has the largest number of tribes amongst all the states of India, constituting $24 \%$ of the total population of the state. Despite several initiatives of the Government of Odisha, the tribal population continues to be alienated from the mainstream society. The GER (Gross Enrolment Ratio) of STs in Higher Education in the State is 6\% against as State's GER of 16.1\%. The position of STS in access to Higher Education in India and Odisha is at Table-5.

Table 5 Gross Enrolment Ratio of Tribals : All India \& Odisha

\begin{tabular}{|c|c|c|}
\hline & Percentage of Population & GER \\
\hline All India & $7 \%$ & $4.4 \%$ \\
\hline Odisha & $24 \%$ & $6 \%$ \\
\hline
\end{tabular}

Source: ASHE 2013 Annual Status of Higher Education of States and UTs in India November 2013 Deloitte

It would thus be seen that the scenario is quite dismal and the tribal belt has been the breeding ground for insurgency \& communal violence. Realizing the problem behind the sluggish pace of transformation into mainstream society, Kalinga Institute of Social Sciences (KISS) was founded by Dr. Achyuta Samanta in the year 1993; with the philosophy that empowerment through education is the only way for concrete emancipation of the tribal population of the state. What started as a fledgling institute with only 125 tribal students in 1993 , KISS has grown in all dimensions to become World's only institution providing free education from Kindergarten to Post-Graduation to around 20000 students.

There are nearly 4657 students having the benefit of higher education with almost 50:50 participation of boys and girls. Some of the significant academic achievements have been $97 \%$ result in +2 Science, Arts and Commerce \& 100\% result in Post-Graduation. Ganeswar Miniaka, a B.Com. Graduate student of Kalinga Institute of Social Sciences (KISS) clears CAT and received call from 6 IIMs. Joins IIM Tiruchirappalli, thirteen Post Graduate students of KISS have qualified for the Rajiv Gandhi National Fellowship for 2012- 13, four Students recruited by Odisha Grameen Bank, four Students recruited by Railway recruitment Board, twenty Four Students have

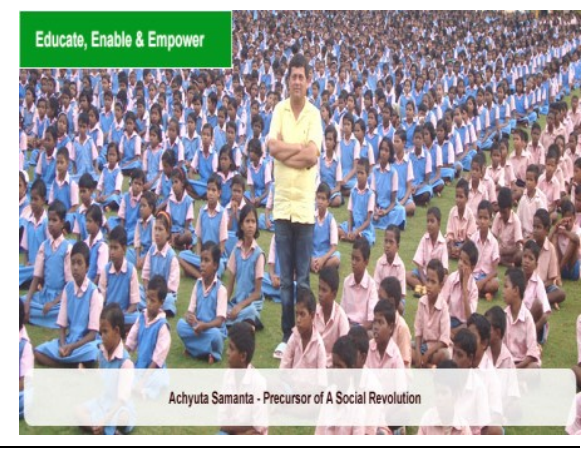


been recruited as teachers under the Sarba Siksha Abhiyaan Sche me of Government of Odisha and eight students were selected by TCS in Campus recruitment Drive. In terms of extracurricular activities Shri B. Barik was selected for Women Rugby World Cup and Shri L. Hembram: UN Youth Assembly at Malala.

It would thus be seen that a uniquely innovative project for mainstreaming the tribal students through education is not only ensuring not only $100 \%$ success at $10+$ level, but also ensuring that some of them compete successfully in converted jobs in Banks, Railway, IT sectors and Civil Services Examination.

\section{Conclusion}

India has made tremendous strides in terms of enrollment in higher education since independence cutting across gender, caste and religion. However in terms of equal access and excellence, India still has considerable distance to traverse. A few concrete measures will go a long way to bridge such dissonance. The delivery mechanism by government agencies is leaky and often patently inept. It would be better to outsource the delivery mechanism of major programs to responsible NGOs. To foster increased access to deprived segments, financial aid and scholarships must be universalized and the overall allocation be substantially augmented. India is caught-up in the cusp of a meaningless debate on Private vs. Public Education; and whether higher education is to be treated as merit or non-merit good. It must be mentioned that in US where most universities are private, their management is out of government control; though most of them receive significant government grants in different ways.

The whole education system in India, primary, secondary, vocational and higher education must be revamped and looked at in a holistic manner. As Prof. Amartya Sen observes "to improve performance Indian Higher Education it is crucially important to reform, indeed to remake the entire system of school education in the country". Global economy has shifted from 'manufacturing centric' to a knowledge driven one, prompting economist Clark Kerr to observe that "on a global scale wealth and prosperity have become more dependent on access to knowledge than access to natural resources". Therefore the challenge is not merely to increase Gross Enrolment Ratio (GER) to $25 \%$ by 2017 but to rev-up the quality and reorient our major policy initiatives. The best entrepreneurial energy have to be harnessed towards the cause of education. As John Maynard Keynes had observed "Difficulty lies not so much in introducing new ideas but in replacing old ones". The new government should take a leaf out of this while formulating the promised new Education Policy for fostering both Equity \& Excellence in higher education.

[1] $\quad 12^{\text {th }}$ Plan Document, Government of India

\section{References}

[2] Agarwal, P.(2007). Higher Education-I-From Kothari Commission to Pitroda Commission. Economic and Political Weekly February 17, 2007

[3] Annual Report, Ministry of Human Resource Development, India, 2010-2011 \& 20-13

[4] Bakshi, P.M. The Constitution of India. Universal Law Publishing Co. Pvt. Ltd. Delhi

[5] Colclough, C. \& Lewin, K. M. (1993): Educating all the Children. Calendon Press, Oxford

[6] Dreze, J. \& Sen, A. An Uncertain Glory India and its Contradictions. Penguin Books India Pvt. Ltd, Panchsheel Park, New Delhi

[7] Guidebook on Promoting Good Governance In Public-Private Partnerships. United Nations Economic Commission for Europe-2008

[8] Human Development Report, 2014-Sustaining Human Progress: Reducing Vulnerabilities and Building Resilience. UNDP

[9] Malhotra, R. India Public Policy Report-2014 Tackling Poverty, Hunger \& Malnutrition. Oxford University Press, Jai Singh Road, New Delhi

[10] Panagariya, A. India - The Emerging Giant. Oxford University Press, Madison Avenue, New York

[11] Pujar, U. Trends in Growth of Higher Education in India. IOSR Journal of Economics and Finance (IOSR-JEF), Volume-2, Issue-6 (Feb. 2014) PP 01-04

[12] Social, Economic and Educational Status of the Muslim Community of India Prime Minister's High Level Committee Cabinet Secretariat Government of India November, 2006. A Report by Rajinder Sachar Committee

[13] Suhag, V. \& Rani, K. (2013). FDI and Higher Education in India. International Journal of Social Science \& Interdisciplinary Research, IJSSIR, Vol. 2 (8), AUGUST (2013) 